\title{
STRATEGI PEMASARAN SMARTPHONE \\ PT VIVO LAMPUNG INDONESIA
}

\author{
${ }^{1)}$ Farah Alhamid, ${ }^{2}$ Rahmat Saleh \\ 1) Dosen Jurusan Teknik Industri Universitas Tulang Bawang \\ FTI - Universitas Tulang Bawang \\ Jl. Gajah Mada No. 34 Kotabaru Bandar Lampung \\ 2) Alumni Teknik Industri Universitas Tulang Bawang
}

\begin{abstract}
PT Vivo Lampung Indonesia is one of the distributors Vivo smartphone in Lampung, targeting local industrial market as a potential market targets. The analysis method used in this research is analysis of IFAS and EFAS matrix, IE matrix, and SWOT matrix. Based on the results of research and data analysis conducted it can be seen that the SWOT matrix analysis resulted in some alternative strategies, among others, to maintain and improve product quality as well as extensive distribution network to increase customer satisfaction and loyalty, improve technology and communication development on smartphone, establish cooperation with potential distributor agent to increase market share, increase the number of smartphone production in accordance with consumer demand, develop a broad market share to enhance consumer brand image, develop product innovation with appropriate selling value, increase consumer confidence in Vivo brand, develop the competitive strategy, also improve and develop maintain the undertaken promotional strategy.
\end{abstract}

Keywords: smartphone, marketing strategy, SWOT

\section{PENDAHULUAN}

\subsection{Latar Belakang}

Perusahanan besar dan kecil saling berpacu untuk merebut tempat pemasaran dengan berbagai macam strategi untuk dapat menjual produk sebanyakbanyaknya, serta terus dapat berkompetisi dan bergerak searah dengan keinginan konsumen, karena pada dasarnya fungsi perusahaan adalah memproduksi barang atau jasa yang dapat diterima serta memenuhi keinginan konsumen.

Barang dan jasa yang ada dipasaran bisa memiliki keseragaman antara produk yang satu dengan produk yang lain. Hal ini dikarenakan produk yang sukses di pasar akan segera diikuti oleh para pesaing dengan menghasilkan produk yang sejenis dengan produk tersebut. Banyaknya keseragaman pada produk-produk yang terdapat dipasar, membuat para konsumen dihadapkan pada banyak pilihan terhadap produk yang diinginkan. Salah satu produk yang perkembangannya cukup pesat dewasa ini adalah smartphone.

Pada era digital dewasa ini, tidak bisa dipungkiri lagi dengan berkembangnya teknologi yang semakin canggih dan modern, perkembangan smartphone secara luas sangat terasa bagi industri perdagangan di Indonesia. Smartphone adalah sebuah perangkat atau teknologi berupa telepon genggam atau mobile versi modern terbaru yang memiliki kelebihan 
dimana spesifikasi sofware dan hardware lebih pintar, fungsi yang lebih cerdas, dan fitur-fitur yang lebih pintar dari ponsel versi biasa sebelumnya. Smartphone yang ada saat ini sangat praktis dan mudah digunakan oleh para penggunanya. Didukung oleh fitur-fitur yang disediakan oleh para produsen yang mengeluarkan smartphone tersebut. Setelah melihat spesifikasi dari beberapa smartphone kebanyakan orang mencari yang sesuai dengan kebutuhannya. Misalnya smartphone tersebut sudah didukung adanya layanan sosial media, layanan office dan lain-lain untuk menunjang pekerjaan.

Vivo Smartphone adalah salah satu merek handphone yang berasal dari negara China yang sudah masuk ke Indonesia. Alasan memilih perusahaan Vivo Smartphone sebagai tempat untuk melakukan penelitian karena Vivo Smartphone adalah suatu produk yang baru saja muncul di Indonesia. Persaingan didunia teknologi yang semakin lama kian menarik dan Vivo Smartphone salah satu pabrikan handphone yang namanya sudah mulai dikenal dikalangan masyarakat seperti di Kota Bandar Lampung. Selain Vivo, dipasaran juga banyak jenis smarphone dengan berbagai macam spesifikasi yang disesuaikan dengan target pasar, produsen smartphone tidak mau kalah dalam persaingan ini. Seperti iPhone, Samsung, Blackberry, Lenovo, dan Oppo yang sering meramaikan pasar smartphone di Indonesia.

Dilihat dari keadaan di atas, maka perusahaan yang berlomba-lomba untuk bersaing haruslah memperhatikan strategi pemasaran yang akan digunakan. Perusahaan dituntut untuk lebih kreatif dalam merancang dan menetapkan strategi pemasaran yang tepat yang akan diterapkan di lapangan agar dapat bersaing dengan perusahaan yang lain.

Suatu perusahaan dapat mengembangkan strategi bersaing dengan cara mencari kesesuaian antara kekuatankekuatan internal perusahaan dan kekuatan-kekuatan eksternal tersebut. Pengembangan strategi bersaing ini bertujuan agar perusahaan dapat melihat secara objektif kondisi-kondisi internal dan eksternal sehingga dapat mengantisipasi perubahan lingkungan eksternal yang sangat penting untuk memperolaeh keunggulan bersaing dan memiliki produk yang sesuai dengan keinginan konsumen dengan dukungan optimal dari sumber daya yang ada (Freddy, 2005 dalam Prawitasari, 2010).

Melihat fenomena yang telah dijabarkan, maka penelitian ini perlu dilakukan untuk mengetahui : strategi pemasaran apakah yang paling tepat diterapkan guna meningkatkan volume penjualan Smartphone dengan tujuan menganalisis dan mengidentifikasi faktorfaktor internal dan eksternal yang merupakan kekuatan, kelemahan, peluang serta ancaman bagi pemasaran smartphone di PT Vivo Lampung Indonesia.

\section{TINJAUAN PUSTAKA}

\subsection{Pengertian Pemasaran}

Menurut Basu Swastha dan Ibnu Sukotjo (2005), pemasaran adalah sistem keseluruhan dari kegiatan usaha yang ditujukan untuk merencanakan, menentukan harga, mempromosikan, serta mendistribusikan barang dan jasa yang dapat memuaskan kebutuhan kepada pembeli yang ada maupun pembeli potensial.

Philip Kotlher dan Gary Amstrong (2004), mendefinisikan pemasaran sebagai proses sosial dan manajerial dimana individu dan kelompok memperoleh apa yang mereka butuhkan dan inginkan melalui penciptaan dan pertukaran produk serta nilai dengan pihak lain.

\subsection{Pengertian Strategi Bauran Pemasaran}

Bauran pemasaran didefinisikan oleh Philip Kotlher dan Gary Amstrong (2004), sebagai seperangkat alat pemasaran taktis yang dapat dikendalikan, yang dipadukan oleh perusahaan untuk menghasilkan 
tanggapan yang diinginkan dalam pasar sasaran.

Sedangkan Suliyanto (2010), mendefinisikan bauran pemasaran merupakan kombinasi dan empat variabel yang merupakan inti dari sistem pemasaran yang dapat dikendalikan oleh perusahaan. Variabel-variabel tersebut dikelompokkan menjadi empat kelompok utama yang dikenal dengan $7 \mathrm{P}$ yaitu:

a. Produk adalah sesuatu yang bias ditawarkan ke pasar untuk mendapatkan perhatian, pembelian, pemakaian, atau konsumsi yang dapat memenuhi keinginan atau kebutuhan (Suliyanto, 2010).

b. Harga adalah jumlah uang yang harus dibayar oleh pelanggan untuk memperoleh produk (Philip Kotlher dan Gary Amstrong, 2004).

c. Menurut Swastha dan Sukotjo (2005), Promosi atau periklanan adalah komunikasi non individu, dengan sejumlah biaya, melalui berbagai media yang dilakukan oleh perusahaan, lembaga non laba, serta individu-individu.

d. Saluran distribusi merupakan saluran yang digunakan untuk menyalurkan barang dari produsen sampai ke tangan konsumen akhir (Suliyanto, 2010).

e. Proses adalah kegiatan yang menunjukkan bagaimana pelayanan diberikan kepada konsumen selama melakukan pembelian barang.

f. Lingkungan Fisik adalah lingkungan fisik tempat jasa diberikan dan tempat dimana pelanggan dan perusahan melakukan interaksi serta komponen lain yang membantu meningkatkan pelayanan jasa yang diberikan.

g. Sumber Daya Manusia adalah Semua pelaku yang memainkan peran penting dalam penyajian jasa sehingga dapat mempengaruhi persepsi pembeli. Elemen dari "people" adalah pegawai perusahaan, dan konsumen.

\subsection{Analisis SWOT}

Menurut Freddy Rangkuti (2006), analisis SWOT adalah identitas berbagai faktor secara sistematis untuk merumusakan strategi perusahaan. Analisis ini berdasarkan logika yang dapat memaksimalkan kekuatan (strength) dan peluang (opportunity), namun secara bersamaan dapat meminimalkan kelemahan (weaknesses) dan ancaman (treath).

\section{METODOLOGI PENELITIAAN}

\subsection{Metode Pengumpulan Data}

Kuesioner diberikan kepada 10 orang responden. Teknik pemilihan responden dilakukan dengan teknik pengambilan sampel secara sengaja (purposive sampling) berdasarkan tugas responden di perusahaan. Hal ini didasarkan pada pertimbangan bahwa responden tersebut berpengaruh dalam pengambilan keputusan, menguasai dan mengetahui informasi yang dibutuhkan, khususnya dalam menentukan strategi pemasaran.

\subsection{Metode Analisis Data}

Analisis data yang dilakukan pada penelitian ini yaitu:

a. Analisis Deskriptif

Analisis deskriptif kualitatif digunakan untuk mengetahui lingkungan perusahaan agar diketahui apa yang menjadi kekuatan, kelemahan, peluang, dan ancaman yang dihadapi perusahaan. Sedangkan analisis kuantitatif digunakan pada matriks IFE, matriks EFE, matriks IE, matriks SWOT, dan matriks QSPM diolah dengan menggunakan program Microsoft Excel.

b. Analisis Lingkungan Perusahaan

Data disajikan berdasarkan analisis lingkungan eksternal dan internal 
perusahaan. Analisis lingkungan eksternal perusahaan meliputi lingkungan makro dan mikro. Para pelaku lingkungan mikro adalah pemasok, pelanggan, pesaing, perusahaan, perantara pemasaran, dan berbagai kelompok masyarakat. Lingkungan makro meliputi lingkungan demografi, ekonomi, alamiah, teknologi, politik, dan budaya. Analisis lingkungan internal perusahaan menggunakan data dan informasi yang berasal dari aspek internal perusahaan, meliputi faktor pemasaran, faktor operasi, produksi, serta SDM.
c. Analisis Matriks Faktor Strategi Eksternal
Matriks EFAS disusun untuk merumuskan faktor-faktor strategi internal tersebut dalam kerangka opportunity and threats perusahaan

Tabel 1. Contoh Matriks EFAS

\begin{tabular}{|c|c|c|c|}
\hline $\begin{array}{c}\text { Faktor-faktor Strategi } \\
\text { Eksternal }\end{array}$ & Bobot & Rating & $\begin{array}{c}\text { Nilai (Bobot X } \\
\text { Rating) }\end{array}$ \\
\hline $\begin{array}{c}\text { Opportunity: } \\
\text { 1. Peluang 1 } \\
\text { 2. Peluang 2 } \\
\text { 3. .............dst. }\end{array}$ & $\mathrm{O} 1(0,0-1,0)$ & $\mathrm{O} 2(1-4)$ & $\mathrm{O} 1 \times \mathrm{O} 2=\mathrm{O} 3$ \\
\hline $\begin{array}{c}\text { Threats: } \\
\text { 1. Ancaman 1 } \\
\text { 2. Ancaman 2 } \\
\text { 3. .............dst. }\end{array}$ & $\mathrm{T} 1(0,0-1,0)$ & $\mathrm{T} 2(1-4)$ & $\mathrm{T} 1 \times \mathrm{T} 2=\mathrm{T} 3$ \\
\hline Total & & & \\
\hline
\end{tabular}

d. Analisis Matriks Faktor Strategi Internal

Matriks IFAS disusun untuk merumuskan faktor-faktor strategi internal tersebut dalam kerangka strenght and weakness perusahaan.

Tabel 2. Contoh Matriks IFAS

\begin{tabular}{|c|c|c|c|}
\hline $\begin{array}{c}\text { Faktor-faktor Strategi } \\
\text { Internal }\end{array}$ & Bobot & Rating & $\begin{array}{c}\text { Nilai (Bobot X } \\
\text { Rating) }\end{array}$ \\
\hline $\begin{array}{c}\text { Strenght }(\mathrm{S}): \\
\text { 1. Kekuatan 1 } \\
\text { 2. Kekuatan 2 } \\
\text { 3. ..............dst. }\end{array}$ & $\mathrm{S} 1(0,0-1,0)$ & $\mathrm{S} 2(1-4)$ & $\mathrm{S} 1 \times \mathrm{S} 2=\mathrm{S} 3$ \\
\hline $\begin{array}{c}\text { Weakness }(\mathrm{W}): \\
\text { 1. Kelemahan 1 } \\
\text { 2. Kelemahan 2 } \\
\text { 3. ..............dst. }\end{array}$ & $\mathrm{W} 1(0,0-1,0)$ & $\mathrm{W} 2(1-4)$ & $\mathrm{W} 1 \times \mathrm{W} 2=\mathrm{W} 3$ \\
\hline Total & & & \\
\hline
\end{tabular}

e. Analisis Matriks Internal Eksternal

Menurut David (2010:345), matriks IE dapat dibagi menjadi tiga bagian besar yang berbeda-beda. Pertama, ketentuan untuk divisi-divisi yang masuk dalam sel I, II, dan IV dapat digambarkan sebagai tumbuh dan membangun. Kedua, divisi- divisi yang masuk dalam sel III, V, dan VII dapat ditangani dengan baik melalui strategi menjaga dan mempertahankan. Ketiga, ketentuan umum untuk divisi yang masuk dalam sel VI, VIII, dan IX adalah panen atau divestasi. 


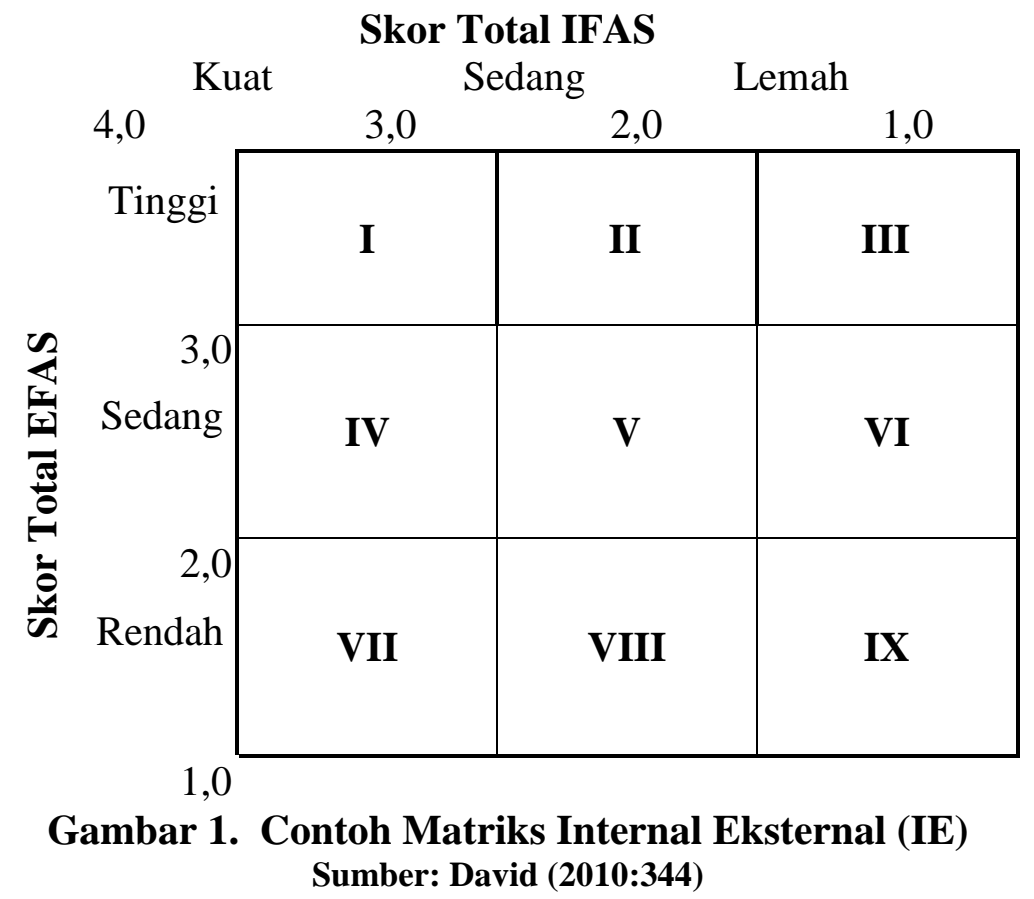

\section{f. Analisis Matriks SWOT}

Analisis SWOT adalah identifikasi berbagai faktor yang secara sistematis untuk merumuskan strategi perusahaan (Rangkuti, 2006). Logika dasar yang dibangun adalah berusaha memaksimalkan kekuatan dan peluang yang secara bersamaan dapat meminimalkan kelemahan dan ancaman.

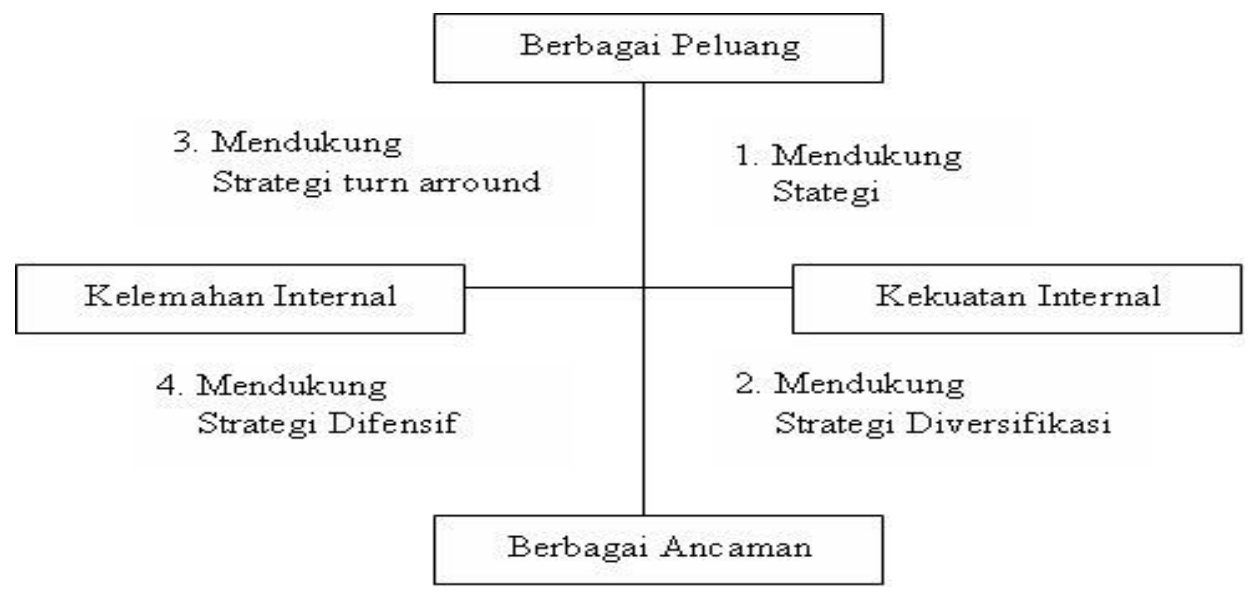

Gambar 2.Diagram Analisis SWOT

Sumber : Freddy Rangkuti, 2006 
Tabel 3. Contoh Matriks SWOT

\begin{tabular}{|c|c|c|}
\hline EFAS & \begin{tabular}{|c} 
Strengths $(S)$ \\
Tentukan 5-10 \\
Faktor-Faktor Kekuatan \\
Internal
\end{tabular} & $\begin{array}{c}\text { Weaknesses }(W) \\
\text { Tentukan 5-10 } \\
\text { Faktor-Faktor } \\
\text { Kelemahan Internal }\end{array}$ \\
\hline $\begin{array}{c}\text { Opportunities }(\mathrm{O}) \\
\text { Tentukan 5-10 } \\
\text { Faktor- Faktor } \\
\text { Peluang Eksternal }\end{array}$ & $\begin{array}{c}\text { Strategi S-O } \\
\text { Ciptakan strategi yang } \\
\text { menggunakan kekuatan } \\
\text { untuk memanfaatkan } \\
\text { peluang }\end{array}$ & $\begin{array}{c}\text { Strategi W-O } \\
\text { Ciptakan strategi } \\
\text { yang meminimalkan } \\
\text { kelemahan untuk } \\
\text { memanfaatkan } \\
\text { peluang }\end{array}$ \\
\hline $\begin{array}{c}\text { Treaths }(\mathrm{T}) \\
\text { Tentukan 5-10 Faktor- } \\
\text { Faktor Ancaman } \\
\text { Eksternal }\end{array}$ & $\begin{array}{c}\text { Strategi S-T } \\
\text { Ciptakan strategi yang } \\
\text { menggunakan kekuatan } \\
\text { untuk mengatasi } \\
\text { ancaman }\end{array}$ & $\begin{array}{c}\text { Strategi W-T } \\
\text { Ciptakan strategi yang } \\
\text { meminimalkan } \\
\text { kelemahan dan } \\
\text { menghindari ancaman }\end{array}$ \\
\hline
\end{tabular}

Sumber : Fredy Rangkuti (2006)

\subsection{Diagram Alur Penelitian}

Alur penelitian diawali dengan tahap persiapan dengan mengkaji masalah yang dihadapi PT Vivo Lampung Indonesia dan menentukan tujuan yang akan diteliti.
Melakukan pengumpulan data dan analisis data menggunakan metode analisis SWOT. Berikut alur penelitian:

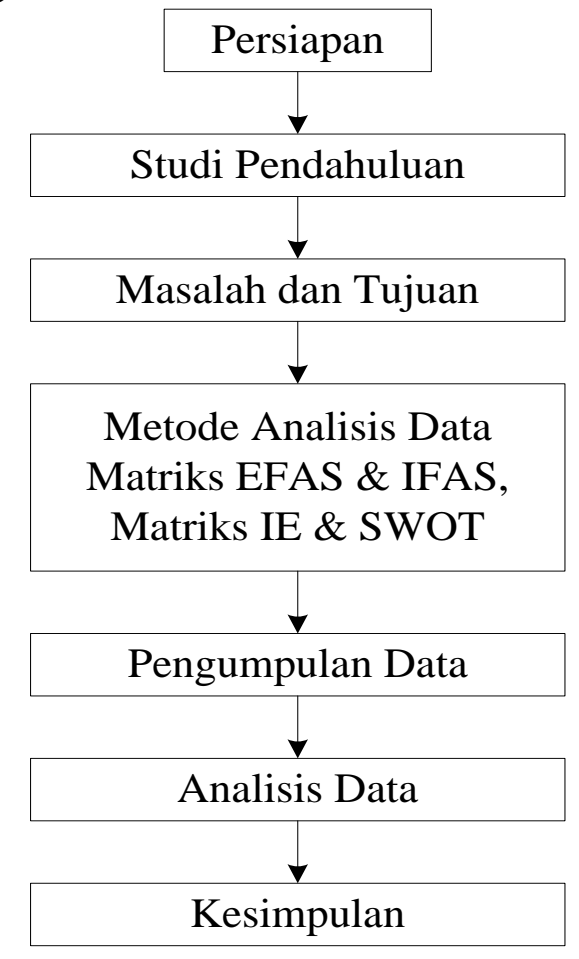

Gambar 3. Diagram Alur Penelitian

\section{HASIL DAN PEMBAHASAN}

\subsection{Matriks Faktor Strategi Internal}

Analisis matriks IFAS merupakan hasil dari identifikasi faktor internal berupa kekuatan (strength) dan kelemahan (weakness) yang berpengaruh terhadap PT Vivo Lampung Indonesia. Hasil analisis matriks IFAS dapat dilihat pada Tabel 4. 
Tabel 4. Matriks IFAS PT Vivo Lampung Indonesia

\begin{tabular}{|c|c|c|c|c|}
\hline No & Faktor-Faktor Strategi Internal & Bobot & Rating & Bobot x Rating \\
\hline \multicolumn{5}{|c|}{ Kekuatan } \\
\hline 1 & Visi dan Misi Perusahaan & 0.072 & 3.4 & 0.2448 \\
\hline 2 & Jaringan Distribusi yang Luas & 0.118 & 3.7 & 0.4366 \\
\hline 3 & Kualitas dan Loyalitas SDM & 0.086 & 3.1 & 0.2666 \\
\hline 4 & Segmentasi Pasar yang Jelas & 0.099 & 3.4 & 0.3366 \\
\hline 5 & $\begin{array}{l}\text { Kualitas Produk Smartphone yang } \\
\text { Dipasarkan }\end{array}$ & 0.093 & 3.5 & 0.3255 \\
\hline 6 & $\begin{array}{l}\text { Sarana dan Prasarana Operasional } \\
\text { Perusahaan yang Memadai }\end{array}$ & 0.075 & 3.6 & 0.2700 \\
\hline 7 & Promosi yang Dilakukan Perusahaan & 0.126 & 3.7 & 0.4662 \\
\hline \multicolumn{5}{|c|}{ Kelemahan } \\
\hline 1 & Pengembangan dan Inovasi Produk & 0.071 & 1.5 & 0.1065 \\
\hline 2 & Kapasitas Produksi Masih Terbatas & 0.069 & 1.6 & 0.1104 \\
\hline 3 & Brand Terkenal Masih Mendominasi & 0.100 & 1.2 & 0.1200 \\
\hline 4 & Brand Image Konsumen & 0.091 & 1.3 & 0.1183 \\
\hline \multicolumn{2}{|r|}{ Total } & 1.000 & & 2.8015 \\
\hline
\end{tabular}

Sumber : Data Diolah, 2018.

Berdasarkan Tabel 4. di atas dapat diketahui bahwa total nilai untuk faktorfaktor strategi internal sebesar 2,8015. Tabel IFAS di atas juga menunjukkan kekuatan utama pada PT Vivo Lampung Indonesia adalah promosi yang dilakukan perusahaan dengan total nilai 0,4662 selanjutnya diikuti jaringan distribusi yang luas dengan total nilai 0,4366. Faktor kelemahan utama pada PT Vivo Lampung Indonesia adalah brand terkenal masih mendominasi dengan total nilai 0,1200 selanjutnya diikuti brand image konsumen dengan total nilai 0,1183 .

\subsection{Matriks Faktor Strategi Eksternal}

Analisis matriks EFAS merupakan hasil dari identifikasi faktor eksternal berupa peluang (opportunity) dan ancaman (threat) yang berpengaruh terhadap PT Vivo Lampung Indonesia. Hasil analisis matriks EFAS dapat dilihat pada Tabel 5. 
Tabel 5. Matriks EFAS PT Vivo Lampung Indonesia

\begin{tabular}{|c|c|c|c|c|}
\hline No & Faktor-Faktor Strategi Eksternal & Bobot & Rating & $\begin{array}{l}\text { Bobot } \mathbf{x} \\
\text { Rating }\end{array}$ \\
\hline \multicolumn{5}{|c|}{ Peluang } \\
\hline 1 & Peningkatan Jumlah Penduduk & 0.121 & 3.5 & 0.4235 \\
\hline 2 & $\begin{array}{l}\text { Perkembangan Teknologi dan } \\
\text { Komunikasi }\end{array}$ & 0.099 & 3.7 & 0.3663 \\
\hline 3 & $\begin{array}{l}\text { Potensi Industri Smartphone yang Masih } \\
\text { Besar }\end{array}$ & 0.089 & 3.7 & 0.3293 \\
\hline 4 & Pangsa Pasar Masih Luas & 0.114 & 3.7 & 0.4218 \\
\hline 5 & $\begin{array}{l}\text { Pertumbuhan Ekonomi yang Cepat di } \\
\text { Negara-Negara Asia dan Malaysia, } \\
\text { Singapura, Jepang, Cina }\end{array}$ & 0.094 & 3.3 & 0.3102 \\
\hline 6 & $\begin{array}{l}\text { Tingginya Loyalitas Konsumen terhadap } \\
\text { Produk Smartphone }\end{array}$ & 0.086 & 3.3 & 0.2838 \\
\hline \multicolumn{5}{|c|}{ Ancaman } \\
\hline 1 & Banyaknya Perusahaan Pesaing & 0.113 & 1.4 & 0.1582 \\
\hline 2 & Adanya Produk Subtitusi & 0.088 & 1.6 & 0.1408 \\
\hline 3 & Persaingan Harga Smartphone & 0.110 & 1.3 & 0.1430 \\
\hline 4 & Fluktuasi Nilai Tukar Rupiah & 0.086 & 1.6 & 0.1376 \\
\hline \multicolumn{2}{|r|}{ Total } & 1.000 & & 2.7145 \\
\hline
\end{tabular}

Sumber : Data Diolah, 2018.

Berdasarkan Tabel 5. di atas dapat diketahui bahwa total nilai untuk faktorfaktor strategi eksternal sebesar 2.7145. Tabel EFAS di atas juga menunjukkan peluang utama pada PT Vivo Lampung Indonesia adalah peningkatan jumlah penduduk dengan total nilai 0,4235, selanjutnya diikuti pangsa pasar masih luas dengan total nilai 0,4218 . Faktor ancaman utama pada PT Vivo Lampung Indonesia adalah banyaknya perusahaan pesaing dengan total nilai 0,1582 , selanjutnya diikuti persaingan harga smartphone dengan total nilai 0,1430 .

\subsection{Matriks Internal Eksternal}

Berdasarkan hasil yang diperoleh dari matriks EFAS dan matriks IFAS maka dapat disusun selanjutnya dalam matriks Internal-Eksternal atau matriks IE. Hasil dari penilaian matriks IE untuk PT Vivo Lampung Indonesia dapat diketahui, berdasarkan matriks IFAS dan matriks EFAS dengan total nilai faktor strategi internal sebesar 2,8015 dan total nilai faktor strategi eksternal sebesar 2.7145 menunjukkan posisi PT Vivo Lampung Indonesia berada pada sel V. Pada posisi ini strategi yang tepat untuk digunakan adalah strategi menjaga dan mempertahankan. Strategi yang dapat diterapkan oleh PT Vivo Lampung Indonesia adalah strategi penetrasi pasar, pengembangan pasar, dan produk. 


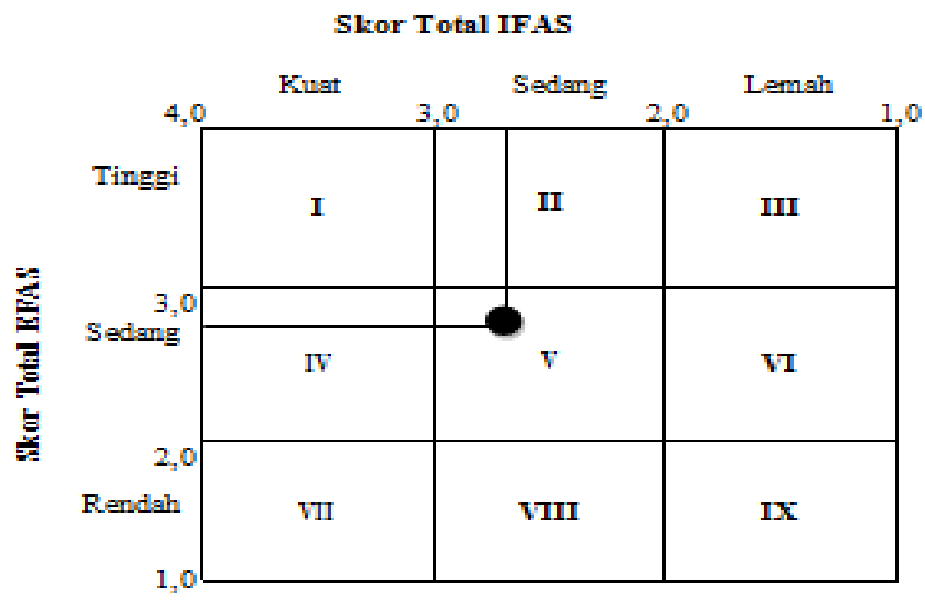

\section{Gambar 4. Matriks Internal dan Eksternal PT Vivo Lampung Indonesia \\ Sumber: Data Diolah, 2018.}

Berdasarkan matriks internal dan eksternal (IE) di atas, menunjukkan kondisi perusahaan berada di sel 5. Pada posisi tersebut perusahaaan dapat menerapkan strategi menjaga dan mempertahankan. Strategi yang dapat diterapkan oleh PT Vivo Lampung Indonesia adalah strategi penetrasi pasar dengan pengembangan pasar dan produk, menciptakan inovasi produk yang baru dan tetap menjaga atau meningkatkan kualitas produk yang sudah ada. Strategi ini merupakan strategi umum yang tidak memiliki implementasi strategi yang lebih teknis pada tingkat perusahaan.. Tujuannya relatif lebih defensif, yaitu menghindari kehilangan penjualan dan kehilangan profit, dimana perusahaan dapat mengembangkan teknologi dan memperluas pasar melalui perkembangan.

\subsection{Matriks SWOT}

Berdasarkan analisis matriks EFAS dan IFAS menunjukkan bahwa untuk faktor-faktor Opportunity nilai skornya 2,1349 dan faktor Threat nilai skornya 0.5796, sedangkan Strength nilai skornya 2,3463 dan Weakness nilai skornya 0.4552 . Maka diketahui nilai Strength diatas nilai Weakness selisih (+) 1.8911 dan nilai Opportunity diatas nilai Threat selisih (+) 1.5553. Dari hasil identifikasi faktorfaktor tersebut maka dapat digambarkan dalam Diagram SWOT, dapat dilihat pada gambar 5 .

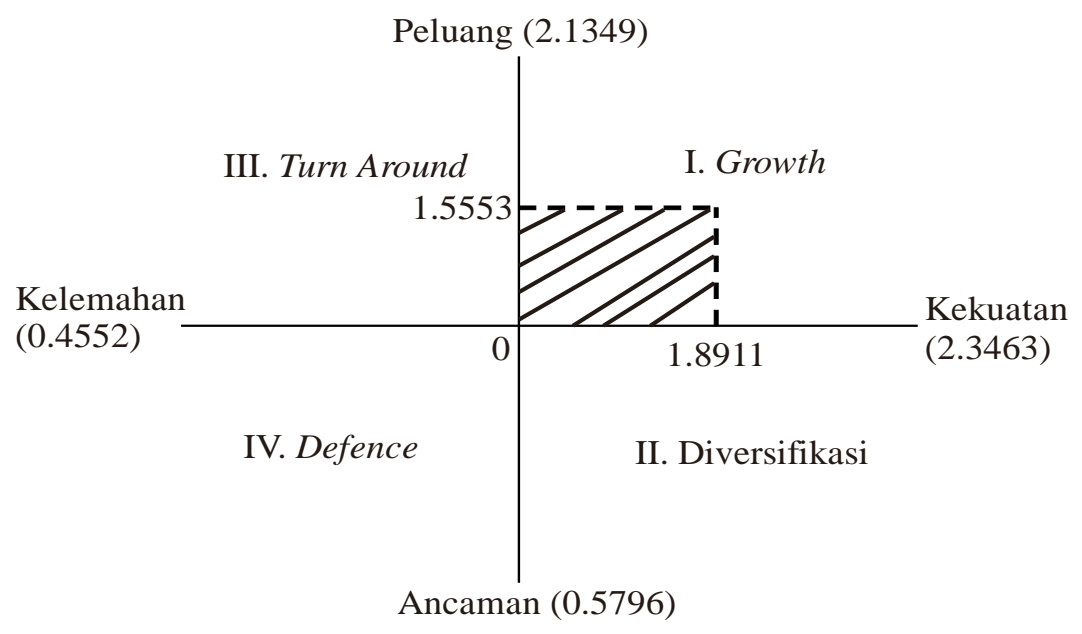

\section{Gambar 5. Diagram Cartesisus Hasil Pengolahan Data Internal dan Eksternal PT Vivo Lampung Indonesia}

Sumber: Data Diolah, 2018 
Berdasarkan gambar diagram cartesius diatas, sangat jelas menunjukkan bahwa PT Vivo Lampung Indonesia telah berada pada jalur yang tepat dengan terus melakukan strategi pengembangan (growth) yang dapat meningkatkan penjualan.
Analisis matriks akan menghasilkan empat jenis strategi utama yaitu strategi SO, W-O, S-T, dan W-T. Hasil dari analisis matriks SWOT pada PT Vivo Lampung Indonesia dapat dilihat pada Tabel 6

Tabel 6. Matriks SWOT PT Vivo Lampung Indonesia

\begin{tabular}{|c|c|c|}
\hline EFAS & $\begin{array}{l}\text { Strengths }(\boldsymbol{S}) \\
\text { 1. Visi dan Misi Perusahaan } \\
\text { 2. Jaringan Distribusi yang Luas } \\
\text { 3. Kualitas dan Loyalitas SDM } \\
\text { 4. Segmentasi Pasar yang Jelas } \\
\text { 5. Kualitas Produk Smartphone yang } \\
\text { Dipasarkan } \\
\text { 6. Sarana dan Prasarana Operasional } \\
\text { Perusahaan yang Memadai } \\
\text { 7. Promosi yang Dilakukan } \\
\text { Perusahaan }\end{array}$ & $\begin{array}{l}\text { Weaknesses }(\boldsymbol{W}) \\
\text { 1. Pengembangan dan } \\
\text { Inovasi Produk } \\
\text { 2. Kapasitas Produksi Masih } \\
\text { Terbatas } \\
\text { 3. Brand Terkenal Masih } \\
\text { Mendominasi } \\
\text { 4. Brand Image Konsumen }\end{array}$ \\
\hline $\begin{array}{l}\text { Opportunities (O) } \\
\text { 1. Peningkatan Jumlah Penduduk } \\
\text { 2. Perkembangan Teknologi dan } \\
\text { Komunikasi. } \\
\text { 3. Potensi Industri Smartphone yang } \\
\text { Masih Besar. } \\
\text { 4. Pangsa Pasar Masih Luas. } \\
\text { 5. Pertumbuhan Ekonomi yang Cepat } \\
\text { di Negara-Negara Asia dan } \\
\text { Malaysia, Singapura, Jepang, Cina. } \\
\text { 6. Tingginya Loyalitas Konsumen } \\
\text { terhadap Produk Smartphone. }\end{array}$ & $\begin{array}{l}\text { Strategi S-O } \\
\text { 1. Mempertahankan dan } \\
\text { meningkatkan kualitas produk } \\
\text { serta jaringan distribusi yang luas } \\
\text { untuk meningkatkan kepuasan dan } \\
\text { loyalitas konsumen. } \\
\text { 2. Meningkatkan perkembangan } \\
\text { teknologi dan komunikasi pada } \\
\text { smartphone. } \\
\text { 3. Menjalin kerjasama dengan agen } \\
\text { distributor yang potensial untuk } \\
\text { menambah pangsa pasar. }\end{array}$ & \begin{tabular}{ll}
\multicolumn{1}{c}{ Strategi W-O } \\
1. & $\begin{array}{l}\text { Meningkatkan jumlah } \\
\text { produksi Smartphone }\end{array}$ \\
sesuai dengan \\
permintaan konsumen. \\
2. & $\begin{array}{l}\text { Mengembangkan } \\
\text { pangsa pasar yang luas } \\
\text { untuk meningkatkan }\end{array}$ \\
brand image konsumen.
\end{tabular} \\
\hline \begin{tabular}{l}
\multicolumn{1}{c}{ Treaths $(\mathbf{T})$} \\
1. Banyaknya Perusahaan Pesaing \\
2. Adanya Produk Subtitusi \\
3. Persaingan Harga Smartphone \\
4. Fluktuasi Nilai Tukar Rupiah
\end{tabular} & $\begin{array}{l}\quad \text { Strategi S-T } \\
\text { 1. Mengembangkan strategi } \\
\text { bersaing. } \\
\text { 2. Meningkatkan, dan } \\
\text { mengembangkan, serta } \\
\text { mempertahankan strategi promosi } \\
\text { yang dilakukan. }\end{array}$ & $\begin{array}{l}\quad \text { Strategi W-T } \\
\text { 1. Melakukan } \\
\text { pengembangan inovasi } \\
\text { produk yang dengan } \\
\text { nilai jual yang sesuai. } \\
\text { 2. Meningkatkan } \\
\text { kepercayaan konsumen } \\
\text { pada brand } \text { Vivo. } \\
\end{array}$ \\
\hline
\end{tabular}

Sumber: Data Diolah, 2018

\subsection{Alternatif Strategi Pemasaran}

a. Strategi S-O (Strength-Opportunities) Strategi yang dapat digunakan yaitu pertama, mempertahankan dan meningkatkan kualitas produk serta jaringan distribusi yang luas untuk meningkatkan kepuasan dan loyalitas konsumen. Kedua, meningkatkan perkembangan teknologi dan komunikasi pada smartphone. Ketiga, menjalin kerjasama dengan agen distributor yang potensial untuk menambah pangsa pasar.

b. Strategi S-T (Strength-Treath)

Strategi yang dapat digunakan yaitu pertama, dengan mengembangkan strategi bersaing. Kedua, meningkatkan dan mengembangkan, serta mempertahankan strategi promosi yang dilakukan. Promosi yang telah dilakukan saat ini sudah menggunakan berbagai media promosi 
tetapi perlu adanya peningkatan untuk mempertahankan promosi yang telah dilakukan menjadi lebih baik.
c. Strategi

Opportunities)

Strategi yang dapat digunakan yaitu meningkatkan jumlah produksi smartphone sesuai dengan permintaan konsumen. Selanjutnya, mengembangkan pangsa pasar yang luas untuk meningkatkan brand image konsumen. Sehingga produk smartphone Vivo bisa mendapatkan kepercayaan yang yang lebih dari para konsumennya.

d. Strategi W-T (Weaknesses- Treath)

Strategi yang dapat dilakukan yaitu pertama, melakukan pengembangan inovasi produk yang dengan nilai jual yang sesuai. Kedua, meningkatkan kepercayaan konsumen pada brand Vivo.

\section{KESIMPULAN}

\subsection{Kesimpulan}

Berdasarkan hasil penelitian yang telah dilakukan pada PT Vivo Lampung Indonesia, maka dapat diambil beberapa kesimpulan sebagai berikut:

1. Analisis matriks IFAS dan EFAS, menghasilkan analisis faktor-faktor internal perusahaan dalam strategi pemasaran smartphone Vivo, yang menjadi kekuatan utama, yaitu promosi yang dilakukan perusahaan dengan total nilai 0,4662 dan kelemahan utama adalah brand terkenal masih mendominasi dengan total nilai 0,1200 . Sedangkan faktorfaktor eksternal perusahaan dalam strategi pemasaran smartphone Vivo yang menjadi peluang utama adalah peningkatan jumlah penduduk dengan total nilai 0,4235 dan ancaman utama perusahaan adalah banyaknya perusahaan pesaing dengan total nilai 0,1582 .

2. Analisis matriks internal eksternal (IE) PT Vivo Lampung Indonesia berada pada posisi sel $\mathrm{V}$, sehingga menerapkan strategi menjaga dan mempertahankan.
3. Analisis matriks SWOT menghasilkan beberapa alternatif strategi, yaitu antara lain mempertahankan dan meningkatkan kualitas produk serta jaringan distribusi yang luas untuk meningkatkan kepuasan dan loyalitas konsumen, meningkatkan perkembangan teknologi dan komunikasi pada smartphone, menjalin kerjasama dengan agen distributor yang potensial untuk menambah pangsa pasar, meningkatkan jumlah produksi Smartphone sesuai dengan permintaan konsumen, mengembangkan pangsa pasar yang luas untuk meningkatkan brand image konsumen, melakukan pengembangan inovasi produk yang dengan nilai jual yang sesuai, meningkatkan kepercayaan konsumen pada brand Vivo, mengembangkan strategi bersaing, juga meningkatkan, dan mengembangkan, serta mempertahankan strategi promosi yang dilakukan.

\section{DAFTAR PUSTAKA}

David, F.R. (2010). Manajemen strategis: Konsep. (Dono Sunardi). Jakarta: Salemba Empat.

J.Staton, William. 2004. Prinsip Pemasaran. Jakarta: Penerbit Erlangga.

Khusnita, A. 2013. Analisis SWOT Dalam Penentuan Strategi Bersaing (Studi pada PT. Bank BNI Syariah Kantor Cabang Syariah Jember).

Kotler, Philip. dan Armstrong Gary. 2004. Dasar-dasar Pemasaran. Jilid 1. Jakarta: PT. Indeks Kelompok Gramedia.

Malik, S. A., Al Khatani, N. S., \& Naushad, M. 2013. Integrating AHP, SWOT and QSPM in Strategic Planning-an Application to College of Business Administration in Saudi Arabia. 
Mardalis. 2009. Metode Penelitian (Suatu Pendekatan Proposal). Edisi 11. Jakarta: PT. Bumi Aksara.

Prawitasari, S.Y. 2010. Analisis Swot Sebagai Dasar Perumusan Strategi Pemasaran Berdaya Saing. Semarang: Universitas Diponegoro. Rahmat, Reny Maulida. 2012. Jurnal Analisis Strategi Pemasaran Pada PT. Koko Jaya Prima Makassar. Fakultas Ekonomi dan Bisnis: Universitas Hasanuddin.

Rangkuti, Freddy. 2006. Analisis SWOT Teknik Membedah Kasus Bisnis. Jakarta:PT. Gramedia Pustaka Utama.
Rangkuti, Freddy. 2006. Strategic Management. Manajemen Strategis. Edisi Keduabelas, Buku Satu. Jakarta: Salemba Empat.

Suliyanto. 2010. Studi Kelayakan Bisnis. Yogyakarta: Penerbit Andi.

Swastha, Basu., Ibnu, Sukotjo. 2005. Pengantar Bisnis Modern. Yogyakarta: Liberty.

Syam, S. 2014. Analisis Strategi Pemasaran untuk Meningkatkan Penjualan Pupuk Organik Cair pada Gapoktan Sipakainge. Skripsi. Fakultas Peternakan. Universitas Hasanuddin. Makassar. 